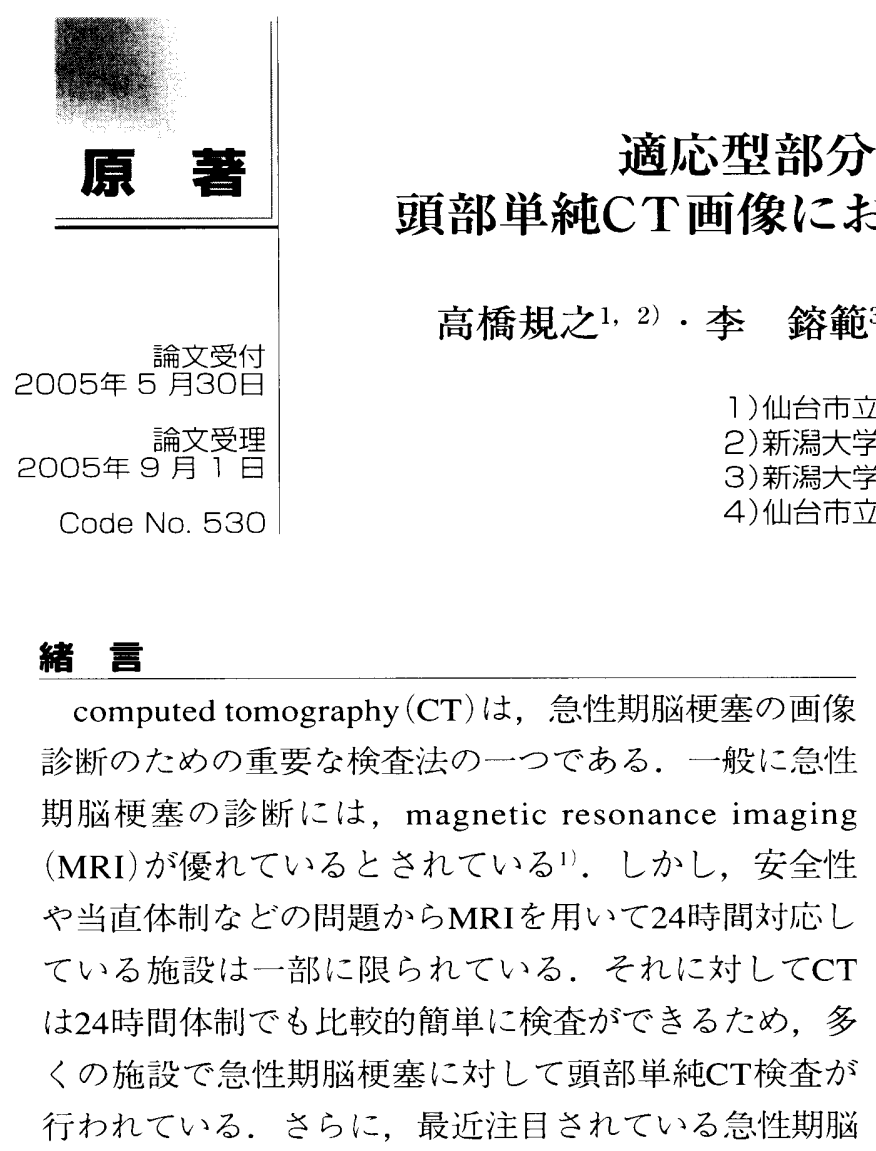

梗塞に対する血栓溶解療法の判断基準にも頭部単純 CT画像が用いられており，そのガイドラインのなか でも, 頭部CT検査の重要性と有効性が強調されてい る2).

急性期脳梗塞の一つである中大脳動脈塞栓症のCT 画像診断では，発症早期に高い確率で出現する初期虚 血変化を検出することが重要である2-4). 初期虚血変 化として，レンズ核の輪郭の不明瞭化または一部欠 損, 皮髄境界の不明瞭化, 脳溝の狭小化, dense MCA signと呼ばれる中大脳動脈の塞栓子の高吸収化が挙げ

\title{
Improvement in Visibility and Detectability of Early Sign of Acute Stroke in Nonenhanced CT Images by Using an Adaptive Partial Smoothing Filter NORIYUKI TAKAHASHI, 1,2) YONGBUM LEE, 3) DU-YIH TSAI,3) KIYOSHI ISHII, 4) and SOUICHIRO KAMIO')
}

1) Department of Radiology, Sendai City Hospital

2) Niigata University Graduate School of Health Sciences

3) Department of Radiological Technology. School of Health Sciences. Faculty of Medicine,

Niigata University

4)Department of Radiology. Sendai City Hospital

Received May 30, 2005; Revision accepted Sept. 1, 2005; Code No. 530

\section{W.}

Detection of early infarct signs on nonenhanced CT is mandatory in patients with acute ischemic stroke. Loss of the gray-white matter interface at the lentiform nucleus or the insular ribbon has been an important early infarct sign, which affects decisions on thrombolytic therapy. However, its detection is difficult, since early infarct sign is of subtle hypoattenuation. To improve the detectability of early infarct sign, image processing that could reduce local noise while preserving edges is desirable. To examine this issue, we devised an adaptive partial smoothing filter (APSF). Since the APSF markedly improves visibility of the normal gray-white matter interface, loss of the gray-white matter interface due to hypoattenuation could be more easily detected. The APSF was applied to clinical CT images in hyperacute stroke patients. Our preliminary results showed that the visibility and detectability of early infarct signs was much improved. To validate the usefulness of the proposed method, two commonly used smoothing filters were also employed for comparison. The results demonstrated the superiority of the APSF. Our proposed APSF can improve the visibility of the gray-white matter interface, thereby enhancing the detectability of early infarct signs.

Key words: Computed tomography, Image processing, Cerebral infarction, Early CT sign

別刷資料請求先：个984-8501 仙台市若林区清水小路3-1

仙台市立病院中央放射線科 高橋規之 宛 
られる。そのなかで，レンズ核の輪郭の不明瞭化また は一部欠損，および皮髄境界の不明瞭化が，最も重要 な初期虚血変化であるといわれている3，4).これらの 不明瞭化や一部欠損は, 虚血によって㾜白質のCT值 (Hounsfield unit：HU) が低下し，死白質一白質の境界 が不明瞭になることによって起こる。一方，量子ノイ ズの存在するCT画像上では, 灰白質一白質のコント ラストはもともとわずかであるため, 正常な在白質一 白質の境界さえも正確に認識することは難しいとされ ている。つまり，虚血によって起こる灰白質一白質の 境界の不明瞭化を検出することは，さらに困難である といえる。そのため, 正確に急性期脳梗塞を診断する ためには医師の経験と熟練が必要であるが2)，その診 断を支援するために，CT検査の撮像線量を増やす， あるいは画像処理によって量子ノイズを低減させる方 法が試みられている5). しかし, 撮像線量の増加は被 ばく線量の増加につながり，被ばく低減意識が高まっ ている今日では一般に受け入れられることは容易では ない.つまり, 何らかの画像処理によって量子ノイズ を低減させ, 初期虚血変化の描出能を向上させる方法 のほうが現実的で望ましい.

このような背景から，われわれは，頭部CT画像に おける急性期脳梗塞の初期虚血変化の描出能を向上さ せることを目的とした画像処理の一手法として, 適応 型部分移動平均フィルタ (adaptive partial smoothing filter：APSF)を提案する.このフィル夕は, Guisらや 千葉らが報告しているコントラスト強調法6,7)に基づ いており，適切なパラメータを設定することで信号成 分を保存しながらノイズ成分のみを低減させることが 可能である.つまり，提案するAPSFのフィルタ特性 から, 頭部CT画像上の脳の灰白質を信号成分とみな し量子ノイズ成分のみを選択的に低減させることで, 正常な灰白質一白質の境界の描出能を向上させること ができる，その結果，虚血による灰白質一白質の境界 の不明瞭化が強調されることになる。すなわち, 正常 な灰白質一白質の境界の描出を良好にすることで，結 果的に不明瞭な扊白質一白質の境界が目立つようにな り初期虚血変化の描出能を向上させることにつなが る. 以下, 提案するAPSFの概要とその初期パラメー 夕を求めるためのシミュレーション実験, および臨床 画像への適用結果についてそれぞれ述べ，最後に考察 してまとめる。

\section{1. 適応型部分移動平均フィルタの概要}

提案する適応型部分移動平均フィルタ (APSF)の処 理手順を述べる。

(1) 原画像に $M \times M$ の移動平均フィルタを適用し前処理 画像を作成する。以降の手順は, すべて前処理画像
で行う.

(2) 注目画素を中心とした初期関心領域の大きさ $W_{\text {max }}(1$ を除く正の奇数)を決定する [Fig. 1(a)].

(3) 初期関心領域内で任意の画素 $(k, l)$ の画素值を $I(k, l)$ とし，以下の条件式を満たす場合には画素 $(k, l)$ を 画素值 1 でラベルし, 条件式を満なさない場合は画 素值 0 でラベルしたマスク画像を作成する [Fig. 1 (a)].

$$
|I(k, l)-I(i, j)| \leqq T
$$

なお, $I(i, j)$ は注目画素 $(i, j)$ の画素值を示す。注目 画素 $(i, j)$ は，初期関心領域内の中心に位置する.

(4) 関心領域のフィルタサイズを再設定する。注目画素 を中心にフィルタサイズWを 3 から奇数ごとに $W_{\text {max }}$ まで順番に拡張していく. その際, 各関心領域の外 周の画素数に占める画素值 0 にラベルされた画素数 の割合 $P_{0}(\%)$ を計算する．P $P_{0}$ が $\alpha \%$ を超えずに $\alpha \%$ に最も近い值になったときのフィルタサイズWを最 終的な関心領域の大きさとする。フィルタサイズを $W_{\text {max }}$ まで拡張しても $P_{0}$ が $\alpha \% に$ 達しない場合は， $W_{\text {max }}$ を最終的な関心領域の大きさとする (Fig. 1 (b)).

(5) 決定した関心領域内でマスク画像の画素值 1 に対 応する領域の平均画素值を求め，その値を注目画素 $(i, j)$ の出力值とする [Fig. $1(\mathrm{c})]$.

(6) (2) から (5)の処理を画像内の各画素 $(i, j)$ で行う. 本手法では，特にしきい值Tによって関心領域内で 信号領域(マスク画像で画素值 1 の領域) とバックグ ラウンド領域(マスク画像で画素值 0 の領域)に分割 される。そして信号領域内の画素值のみが平滑化の 計算に用いられる。つまり，これは信号領域とバッ クグラウンド領域間のエッジを保存しながらノイズ 低減を行うことを意味しており，提案するAPSFの大 きな特徴といえる。う一つのAPSFの特徴として は，しきい值Tによって注目画素とその周囲の画素値 の関係を考慮しながらフィルタサイズが適応的に決 定される点である。これら二つの特徴は，いずれも しきい值Tに大きく依存しており，しきい值TがAPSF の最重要パラメータであるといえる。なお，しきい 值 $T$ 以外のパラメータ $M, W_{\max }, \alpha$ \&PSFの性能を左 右するが，今回はそれらの設定值は経験的に $M=5$, $W_{\max }=13, \alpha=60$ とし, 臨床画像へ応用する際のしきい 值Tの基準值のみを次のシミュレーション実験で求め た。

\section{2. シミュレーション実験}

シミュレーション実験の目的は，しきい值Tの変化 によるAPSFのノイズ低減とエッジ保存の効果を具体 
的に数值化して検証すること，そしてそれらに 基ついて臨床画像にAPSFを適用する際の基準 となるしきい值 $T$ を求めることである，以下， まずはシミュレーション画像の作成について述 ベ, その後, 実験方法と結果扔よびしきい值 $T$ の基準值の決定についてそれぞれ述べる.

\section{2-1 シミュレーション画像の作成}

シミュレーション画像には, 頭部CT画像にお ける灰白質一白質を模擬した画像を用いた。具 体的には，白質を模擬した信号 (simulated white matter：SWM) として，円柱ファントムである catphan ${ }^{\circledR}$ CTP445(ファントム・ラボラトリー社 製)をCTで撮像し，そこで得られた画像にさら に灰白質を模擬した信号 (simulated gray matter：SGM）を加えた。SGMは，サイズを $40 \times 100$ ピクセルとし，撮像された円柱ファント ムに単純に6HUを加算することで作成した。 この值は，灰白質と白質の平均 CT值の差から 決定した8)。作成したシミュレーション画像を Fig. 2に示す。なお，用いたCT装置はSOMATOM Volume Zoom (シーメンス旭メディテック社製) で，撮像条件は，管電圧 $120 \mathrm{kV}$ ，管電流×撮像時 間 $300 \mathrm{mAs}$ ，スライス厚 $10 \mathrm{~mm}$, FOV $250 \mathrm{~mm}$,

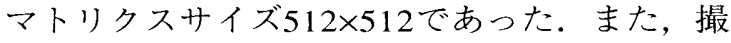
影ごとの画素值のばらつきを考慮して，同じ条 件で10回ファントム撮影を行い，10枚のシミュ レーション画像を作成し以降の実験で用いた。

\section{2-2 実験方法と結果}

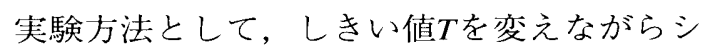
ミュレーション画像にAPSFを適用し，しきい 值Tに関するノイズ低減とエッジ保存の度合い をそれぞれの指標で数值化した．用いた二つの 指標について述べながら，得られた結果を合わ せて示す。

まず，ノイズ低減の指標には標準偏差 (standard deviation：SD)を用いた。具体的には，20×20の大き さの関心領域 (region of interest：ROI)をSGM上に設 定し，そのROI内のSDを求めた。 そして，しきい値 $T$ を 0 から 5.0 まで 0.5 おきに変えながらAPSFをシミュ レーション画像に適用し，TとSDの相関関係を調べ た．得られたTとSDのグラフをFig. 3(a)に示す。一般 的にSDの值が小さいほどノイズも少ないとされてい る。つまり，Fig. 3(a)のグラフから，Tが約3.0までは ほぼ線形にノイズが低減していることが分かる。そし て，Tが3.0を超えたあたりからノイズ低減の効果が緩 やかになり，やがてほぼ頭打ちになっている。このこ

\begin{tabular}{|c|c|c|c|c|c|c|c|c|c|c|c|c|c|c|c|c|c|}
\hline \multicolumn{9}{|c|}{$W \max$} & & & & & & & & & \\
\hline 31 & 36 & 41 & 43 & 45 & 45 & 45 & 36 & 46 & 1 & 1 & 0 & 0 & 0 & 0 & 0 & 1 & 0 \\
\hline 32 & 35 & 35 & 35 & 36 & 36 & 34 & 35 & 45 & 1 & 1 & 1 & 1 & 1 & 1 & 1 & 1 & 0 \\
\hline 31 & 36 & 36 & 33 & 34 & 33 & 35 & 50 & 45 & 1 & 1 & 1 & 1 & 1 & 1 & 1 & 0 & 0 \\
\hline 29 & 35 & 35 & 36 & 33 & 34 & 50 & 50 & 50 & 0 & 1 & 1 & 1 & 1 & 1 & 0 & 0 & 0 \\
\hline 25 & 34 & 34 & 35 & 35 & 34 & 50 & 51 & 51 & 0 & 1 & 1 & 1 & . & 1 & 0 & 0 & 0 \\
\hline 32 & 35 & \begin{tabular}{|l|}
33 \\
\end{tabular} & 32 & 34 & 33 & 51 & 35 & 50 & 1 & 1 & 1 & 1 & 1 & 1 & 0 & 1 & 0 \\
\hline 39 & 25 & 34 & 35 & 34 & 45 & 46 & 45 & 45 & 1 & 0 & 1 & 1 & 1 & 0 & 0 & 0 & 0 \\
\hline 25 & 24 & 25 & 32 & 20 & 20 & 21 & 20 & 43 & 0 & 0 & 0 & 1 & 0 & 0 & 0 & 0 & 0 \\
\hline 24 & 25 & 31 & 32 & 32 & 20 & 45 & 43 & 41 & 0 & 0 & 1 & 1 & 1 & 0 & 0 & 0 & 0 \\
\hline
\end{tabular}
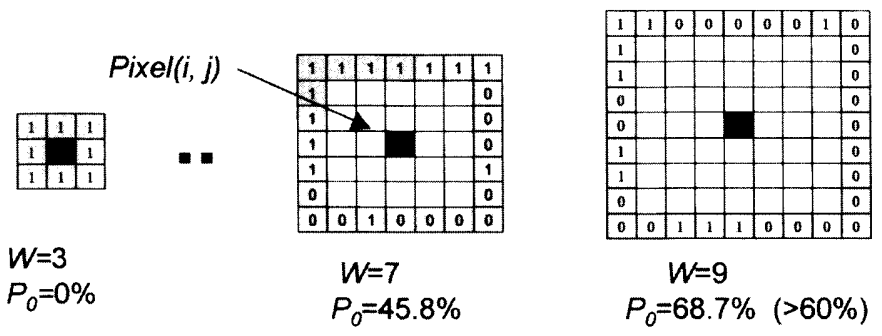

$W=9$

$P_{0}=68.7 \%(>60 \%)$

\begin{tabular}{|l|l|l|l|l|l|l|}
\hline 1 & 1 & 1 & 1 & 1 & 1 & 1 \\
\hline 1 & 1 & 1 & 1 & 1 & 1 & 0 \\
\hline 1 & 1 & 1 & 1 & 1 & 0 & 0 \\
\hline 1 & 1 & 1 & 1 & 1 & 0 & 0 \\
\hline 1 & 1 & 1 & 1 & 1 & 0 & 1 \\
\hline 0 & 1 & 1 & 1 & 0 & 0 & 0 \\
\hline 0 & 0 & 1 & 0 & 0 & 0 & 0 \\
\hline
\end{tabular}

Fig. 1 Adaptive neighborhood selection with a threshold a value of $T=5$.

(a) Left: Wmax window around pixel value $I(i, j)=35 \quad$ b (black). Right: Mask values associated with Wmax window. For example, the pixel value $I(k, l)=33 \quad c$ (gray) within $W \max =9$ is assigned a binary mask value 1 , because $|I(k, l)-I(i, j)| \leqq T$ (i.e., $|33-35| \leq 5)$.

(b) The percentage of zeros $\left(P_{0}\right)$ is computed over the region of external area (gray) of window $W=3,5,7$. The pixel $(i, j)$ is assigned the window $W=7$, when $P_{o}$ is set at $60 \%$.

(c) The pixel value of pixel $(i, j)$ in the processed image $l$ ' is the mean value in image $l$ of pixels labeled as a binary mask value 1 (gray) in the assigned window $W=7$.

とから今回用いたCT画像の量子ノイズの信号差は, 約 $3 \pm 0.5 \mathrm{HU}$ 程度の範井内にあることがうかがえる. なお, Fig. 3(a)のグラフに拈いて，一つのしきい值 $T$ に対応するSDの值は, 10枚のシミュレーション画像 ごとに得られるSDの值の平均值とした。

ここで，しきい值Tに小数点が含まれる理由は, APSFの処理手順 (1)の移動平均フィル夕処理時に, 出 力画素値として整数值ではなく小数值を切り捨てずに そのまま用いているためである，画素值に小数を含む ようにしたのは，SGMとSWMの差がわずか $6 \mathrm{HU}$ と小 さいことから，整数值よりも細かくしきい值 $T$ を設定 できると考えたからである。 


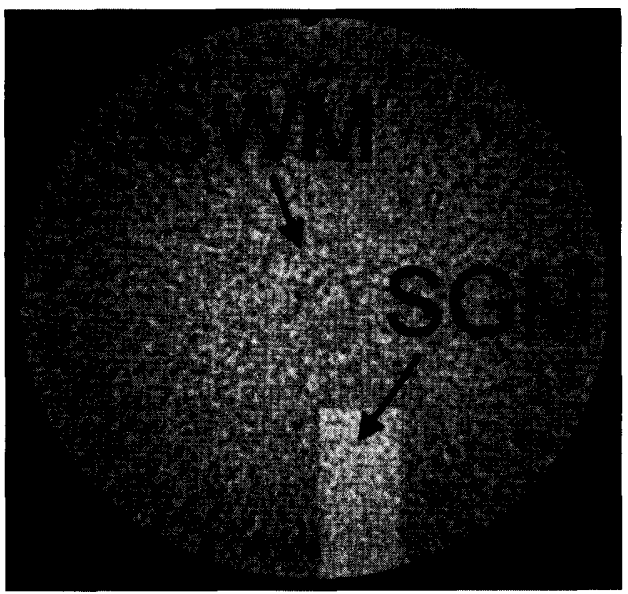

Fig. 2 A simulated image obtained by adding computer-simulated gray matter (SGM) to a phantom CT image that is considered as simulated white matter (SWM).
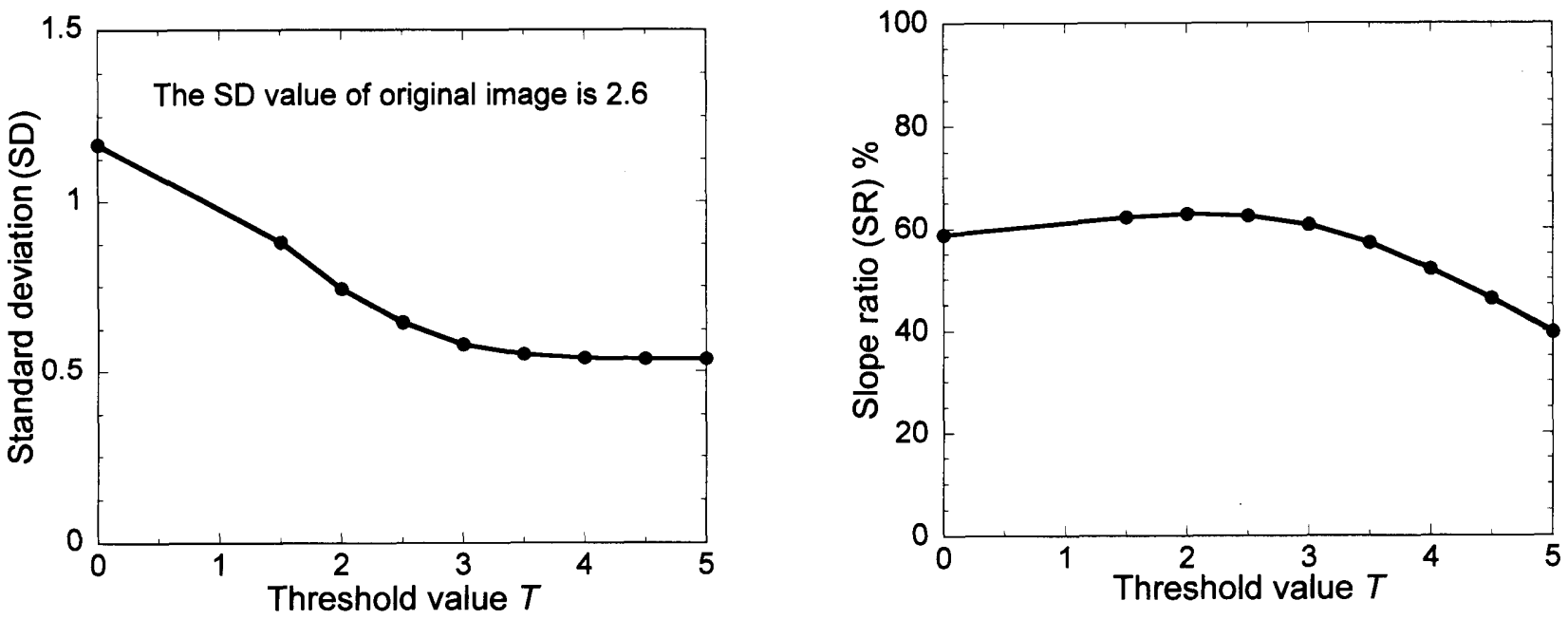

Fig. 3 Graphs of SD and SR as functions of the threshold value $T$.

(a) Graph of SD vs $T$.

(b) Graph of SR vs $T$.

次に，エッジ保存の指標について述べる。エッジ保 存の指標には傾斜比 (slope ratio：SR)というものを定 義して用いた。 その定義式を式(2)に示す.

$$
S R(\%)=\Delta P_{p r} / \Delta P_{\text {org }} \times 100
$$

$\Delta P_{p r}$ と $\Delta P_{o r g}$ は，それぞれAPSF処理後の画像と原画 像におけるSGMとSWMのエッジの傾きを表してい る。具体的には，SGMとSWM間のエッジ上に $80 \times 40$ の大きさのROIを設定し, そのROI内の平均プロファ イルから $\Delta P_{p r}$ と $\Delta P_{\text {org }}$ を求めた $($ Fig. 4). 。して, SDと 同様に，しきい值 $T$ を 0 から 5.0 まで 0.5 おきに変えな がらAPSFをシミュレーション画像に適用し， $T$ とSR の相関関係を調べた。得られた $T$ とRのグラフをFig. 3 (b)に示す. 式(2)から，SRの值が大きいほどエッジ がよく保存されているといえる。つまり，Fig. 3(b)の グラフから，Tが約2.5あたりまではエッジがよく保存
されていることが分かる。そして，Tが2.5を超えたあ たりからエッジの保存度が低下しはじめている。本実 験では，SGMとSWM間のエッジを 6HU差として作成 しているが，そこには先のSDの結果で述べたように $3 \pm 0.5 \mathrm{HU}$ 差程度の量子ノイズが加わることになる。

つまり，実際にエッジとして認識しているのは $3 \pm 0.5$

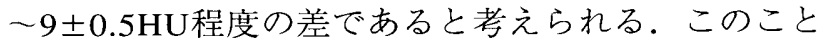
から，Tが2.5〜3.5を超えたあたりから，SGMとSWM 間のエッジの一部がノイズとみなされ，エッジのぼけ が大きくなりはじめることが予想される. Fig. 3(b)の SRのグラフは，このことをよく表した結果となって いる.なお，Fig. 3(b)のグラフにお゙いて，一つのしき い值 $T$ に対応するSRの值は，10枚のシミュレーション 画像ごとに得られるSRの值の平均值とした。

Fig. 5に，しきい值Tを0，1.0，2.5，3.0，5.0に設 定したときのAPSF好理後のシミュレーション画像の 


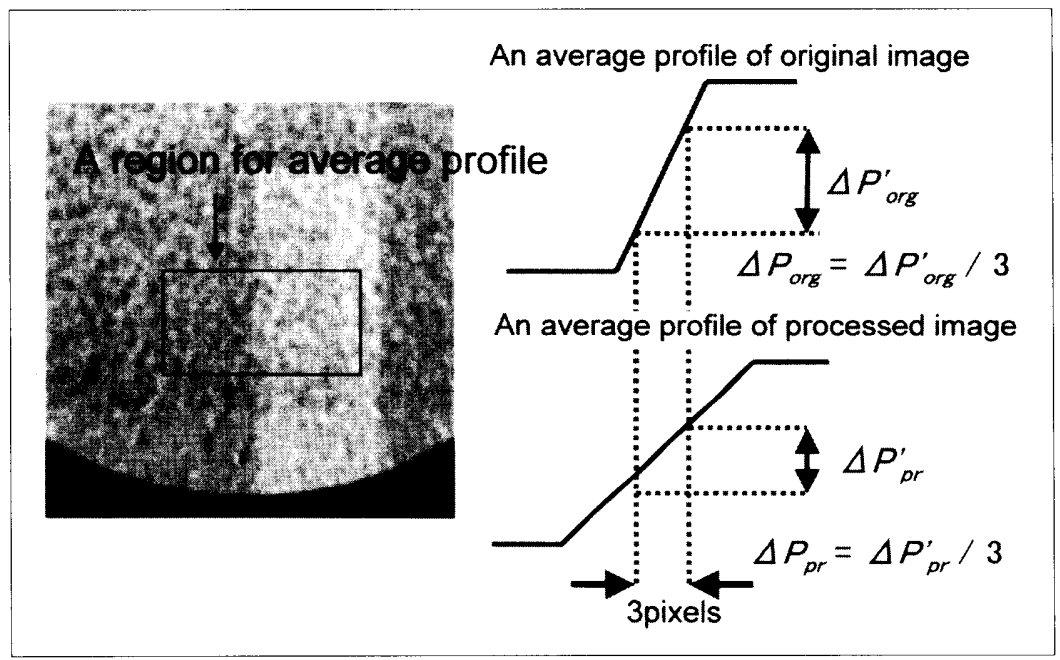

Fig. 4 Slope ratio (SR) defined for the performance evaluation.

一部を示す.Fig. 3(a)のSDのグラフが示すとおり，T が0，1.0ではまだノイズが十分に低減されずに残って いることが画像からも確認できる。一方，Tが2.5, 3.0，5.0では，原画像と比べよくノイズが低減されて いるのが分かる。また，Tが25.0の画像では，SGMと SWM間のエッジが, 2.5 と3.0の画像に比べぼけている のが確認できる．Tが2.5の画像では，3.0の画像に比 ベ少しノイズが多いが, SGMとSWM間のエッジのぼ けがわずかに少ないことが確認できる。これもFig. 3 (b)のSRのグラフの傾向をそのまま表しているといえ る.

\section{2-3 しきい值Tの基準值の決定}

シミュレーション実験の結果から, 臨床画像に APSFを適用する際のしきい値 $T$ の基準値は $3 \pm 0.5 \mathrm{HU}$ の範囲内が望ましいと判断できる。 その理由は, Fig.

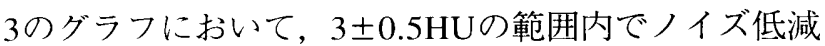
の度合い $(\mathrm{SD})$ は頭打ちになり，エッジ保存の度合い (SR)は低下しはじめているからである，ノイズ低減 を優先的に考慮すると，Tの基準值は3.0〜 3.5が妥当 であると考えられる。一方，エッジ保存を優先的に考 えた場合は，Fig. 3(b)でSRのピークを示している 2.5 が望ましい，本実験では，Fig.5で示したように，Tが 2.5でも視覚的に十分ノイズが低減されていること， 拉よびエッジ保存の度合い $(\mathrm{SR})$ を優先的に考慮し， $T$ の基準值を $2.5 に$ 設定することにした。

\section{3. 鲌床画像への度用}

まず初めに，シミュレーション実験で得たしきい值 Tの基準值が，臨床画像においても適当であるかを検 証するために，正常な頭部CT画像に $T$ を基準值 \pm 1.0 の 範囲で設定したAPSFを適用し，その効果を画像から
確認してみた。しきい值Tを1.5，2.5，3.5に設定した ときの画像の一例をFig. 6に示す。なお，この画像の

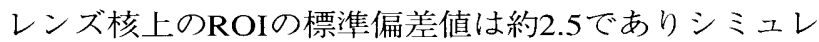
ーション画像のノイズレベル $(\mathrm{SD}=2.6)$ と同程度であ る.Tが1.5のときは細かいノイズがまだ目立ち，Tが 3.5のときはレンズ核の輪郭がぼけはじめていること が分かる。このことから，シミュレーション実験で得

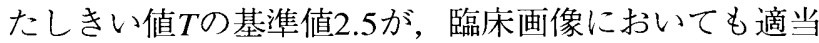
であると判断される，そのため，以降の臨床画像への APSFの適用では，すべてしきい值 $T$ 基準值どおりに 2.5に設定した。 なお，Fig. 6に示した原画像と処理画 像では，観察条件(ウィンドウ幅)が異なっている。ウ インドウレベルは同じ35HUであるが，ウィンドウ幅 は原画像では80HU，処理画像では20HUとしている. 原画像の80HUは，頭部CT検査で普段用いられている ウィンドウ幅である．処理画像でウィンドウ幅を 20HUとしているのは，APSFによってノイズが大幅に 低減され，狭いウィンドウ幅で観察してもノイズが強 調されないためである。一方，原画像ではウィンドウ 幅が狭すぎるとノイズが強調され，レンズ核の輪郭が かえって確認しづらくなる場合がある．Fig. 6(e)に Fig. 6(a)をウィンドウ幅20HUで表示した画像, Fig. 6 (f) にFig. 6(c) をウインドウ幅80HUで表示した画像を それぞれ示す。Fig. 6(e)ではノイズが目立ち，Fig. 6 (f)ではレンズ核の輪郭がFig. $6(\mathrm{c})$ より確認しにくくな っている，本論文では，この表示ウィンドウ幅の違い も提案法の一部とみなし，以後に提示するAPSFによ る処理画像すべてをウインドウ幅20HUで表示する. なお，20HUより狭いウィンドウ幅を用いると頭蓋内 の情報の久落が起きるため経験的にこの值にしてい る。また，頭部CT画像の観察条件を変えたときの初 期虚血変化の検出への影響については，後で考察す 


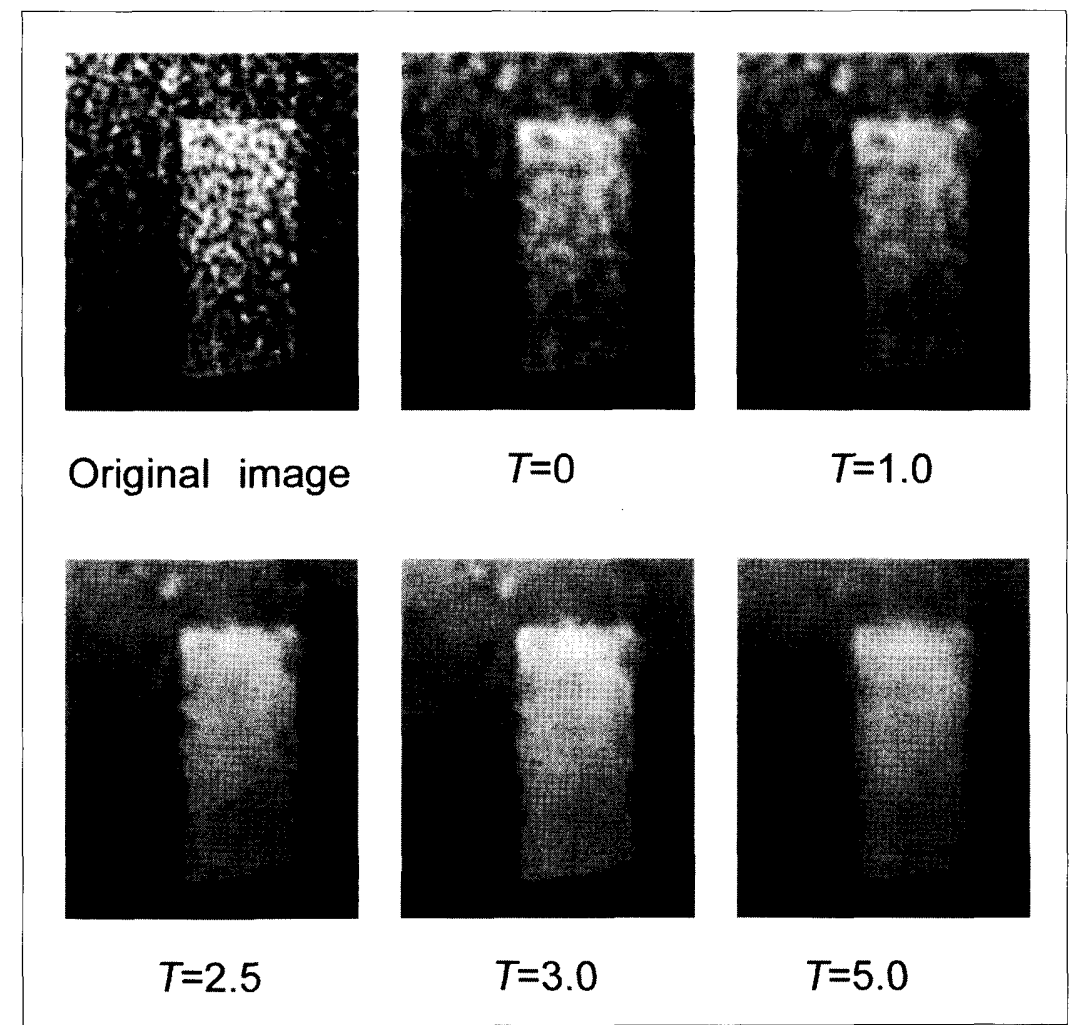

Fig. 5 Processed images obtained by varying threshold value $T$.

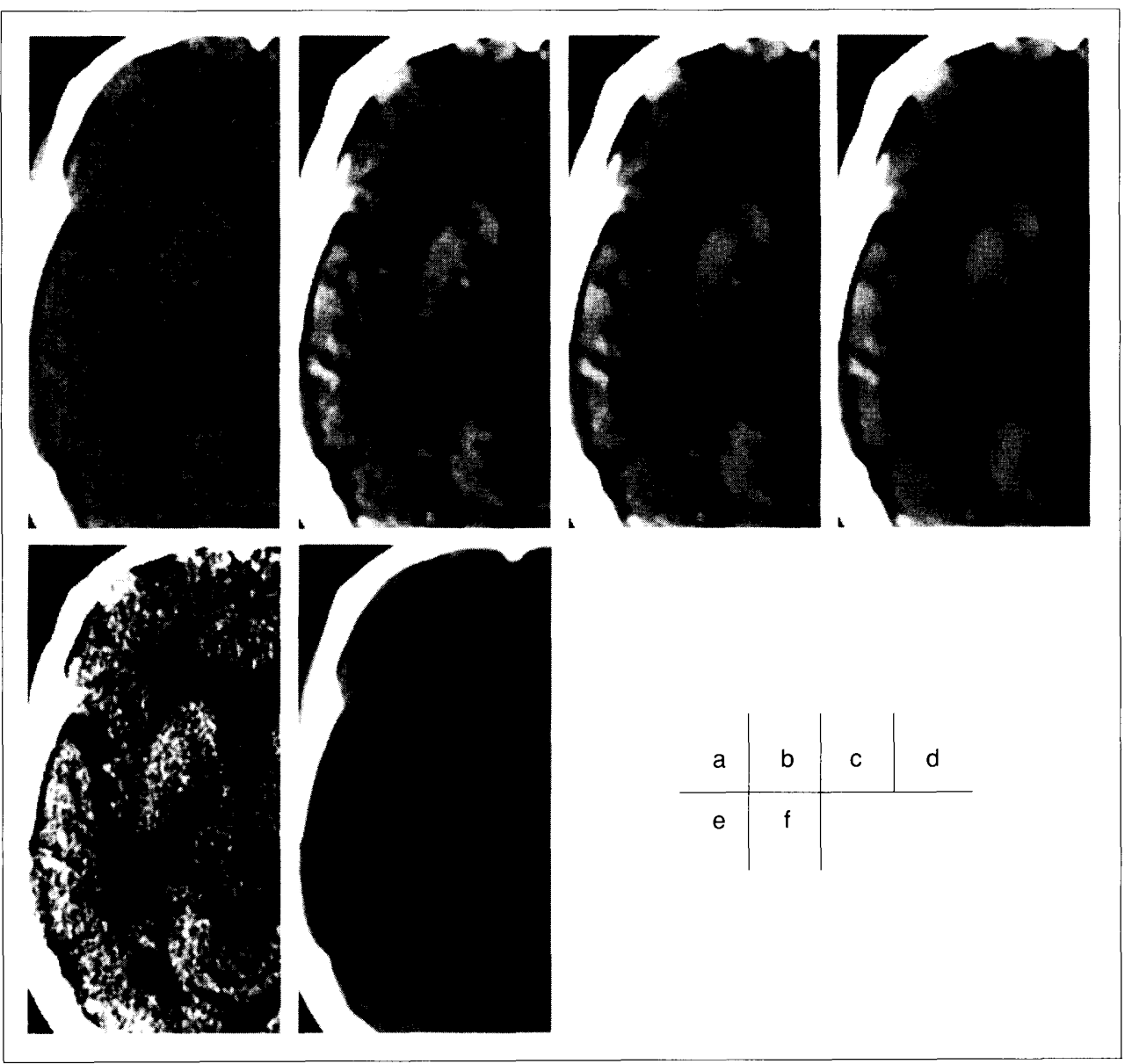

Fig. 6 Nonenhanced CT images after applying the APSF with various threshold values and different window widths (WW)
(a) Original image
(b) $T=1.5$
(c) $T=2.5$
(d) $T=3.5$,
(e) (a) with narrow setting (WW, $20 \mathrm{HU}$ ),
(f) (c) with standard set- ting (WW, $80 \mathrm{HU}$ ) 
る.

次に, 本手法を 4 例の中大脳動脈領域塞栓性梗塞の CT画像に適用した。撮像に使用した装置はProSeed Accell (GE横河メディカルシステム社製)であり，撮像

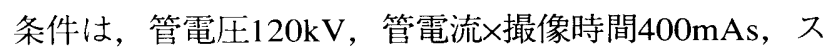
ライス厚 $10 \mathrm{~mm}$, FOV $250 \mathrm{~mm}$, マトリクスサイズ $512 \times 512$ とした。

[症例 1 ]左中大脳動脈塞栓性梗塞の発症 1 時間 45 分後 の63歳女性の頭部CT画像とAPSF処理後の画像をそれ ぞれFig. 7 (a) とFig. 7(b) に示す. 原画像では左側の梗 塞によるレンズ核の一部欠損を正確に指摘することは 困難であるが，APSF処理後の画像では虚血によるCT 值の低下が強調され，レンズ核の一部欠損が認識でき る [Fig. 7(b)の矢印部分]. 発症 7 日後のCT画像をFig. 7 (c) に示す. 左中大脳動脈領域に低信号域が出現し, 急性期の脳梗塞が明らかになっている。

[症例 2]左中大脳動脈塞栓性梗塞の発症 1 時間30分後 の83歳男性の頭部CT画像とAPSF処理後の画像をそれ ぞれFig. 7(d) とFig. 7 (e) に示す. 原画像では初期虚血 変化を指摘することが困難であったが，APSF処理後 の画像では右側と比べて左側のレンズ核が低吸収とな り輪郭の不明瞭化が認められる [Fig. 7 (e)の矢印部 分了。さらに，島皮質の不明瞭化も明瞭に描出されて いる[Fig. 7 (e)の矢頭部分]. 発症 7 日後のCT画像を Fig. 7(f)に示す. 左側のレンズ核から島皮質の低吸収 域が明らかになり内部に高吸収域が認められ, 出血性 脳梗塞と診断された。

[症例 3]左中大脳動脈塞栓性梗塞の発症 1 時間30分後 の60歳男性の頭部CT画像とAPSF処理後の画像をそれ ぞれFig. 7 (g) とFig. 7(h) に示す. 原画像で左側のレン ズ核の輪郭が少し不明暸化している. APSF処理後の 画像では，左レンズ核の輪郭の不明瞭化がはっきりと 認められる $\mathrm{Fig} .7(\mathrm{~h})$ の矢印部分]. 発症 7 日後のCT 画像 $[$ Fig. 7(i)]で, 左側のレンズ核から島皮質に低信 号域が認められ，急性期の脳梗塞であった。

〔症例 4〕詳細は考察で述べる (Fig. 8).

原画像と比較した場合, APSFの適用により, すべ ての症例に扔いて正常なレンズ核の輪郭扔よび皮髄境 界が強調されていた。 それに伴って，わずかな灰白質 のCT值の低下である初期虚血変化の描出能が向上し ていることが確認できた。

\section{4. 考 雲}

脳梗塞の発症 5 時間以内に行われたCT検査で認め られた初期虚血変化は，CT值の低下に上る死白質一 白質の境界の不明瞭化が $81 \%$, 脳溝の消失が $38 \%$, 中 大脳動脈の高吸収が $47 \%$ \%ちったという報告がある91. また緒言でも述べたように，すべての初期虚血変化の
なかでCT值の低下による灰白質一白質の境界の不明 瞭化が最も頻繁にみられたとも報告されている3 ${ }^{3,4)}$. したがって，脳梗塞の超急性期の診断ではCT值の低 下による灰白質一白質の境界の不明瞭化が最も重要な 所見であり，本手法は，その描出能の向上を可能にし ている. 発症早期のCT值の低下は細胞性浮腫に伴う 水成分の増加が原因であり，1\%の組織水成分の増加 はCT值を $2 \mathrm{HU}$ から 3HU低下させるという報告があ $3^{10)}$. シミュレーション画像で用いた原画像のSDの 值は約2.5であり，臨床画像に置き換えると脳虚血に よるCT值の低下 $(2-3 \mathrm{HU})$ と同程度となる。すなわ ち, 通常のCT画像では量子ノイズの影響で脳虚血に よるわずかなCT值の変化を認識することは難しい. それに対して, APSF処理後の画像のSDの值は約0.6 （T=2.5のとき）であり，脳虚血によるCT值の低下より も十分に量子ノイズが低減されている。こうした理由 から，わずかなCT値の低下として現れる初期虚血変 化に対しても，本手法を用いることである程度は強調 することが可能であると考えられる.

本論文で使用した臨床画像は，急性期脳梗塞の診断 経験が豊富な医師が読影を行えばすべて正確な診断が 可能であると思われる。しかし，実際には発症早期に 初期虚血变化を指摘できず，CT検查の後行われた MRIで脳梗塞の領域が確認された症例 [症例 $2:$ Fig. 7 (d) ]が含まれている. 救急の現場では，急性期脳梗塞 の専門医が担当している場合は少なく，むしろ大多数 の施設では，急性期脳梗塞に対する非専門医やさらに 研修医が救急を担当しているのが実状であるといわれ ている。こうした現状に执いて，本手法により初期虚 血変化の描出能が向上できれば，救急における急性期 脳梗塞の検出率の向上が期待できる. 今後, 本手法の 臨床的有効性をさらに評価するためにはより多数の脳 梗塞症例を用いた分析が必要であると考えている。

モニタで診断する場合，一般に用いられる観察条件 より狭いウィンドウ幅で観察すると急性期脳梗塞の検 出率が向上するといわれている11).Fig. 8に，異なる 観察条件の頭部CT画像と本手法による処理画像を示 す。この症例では，一般的なウィンドウ幅である 80HUを用いた場合では梗塞によるレンズ核の一部欠 損を指摘することは難しい[Fig. 8 (a) ]. また，狭いウ インドウ幅 $(20 \mathrm{HU})$ を用いてもレンズ核の一部欠損を 検出することは困難である $[$ Fig. 8(b) ] ，しかし，本手 法による処理画像では，レンズ核の一部欠損が明瞭に 描出されている[Fig. 8(c)]. Fig. 8(d)に発症 4 日後の CT画像を示す。本手法による処理画像では, 解剖学 的な情報(レンズ核の輪郭など)は損なわずにノイズ成 分のみが十分に低減されているため，ウィンドウ幅を 狭める $(20 \mathrm{HU}$ 程度に)ことによって虚血による灰白質 

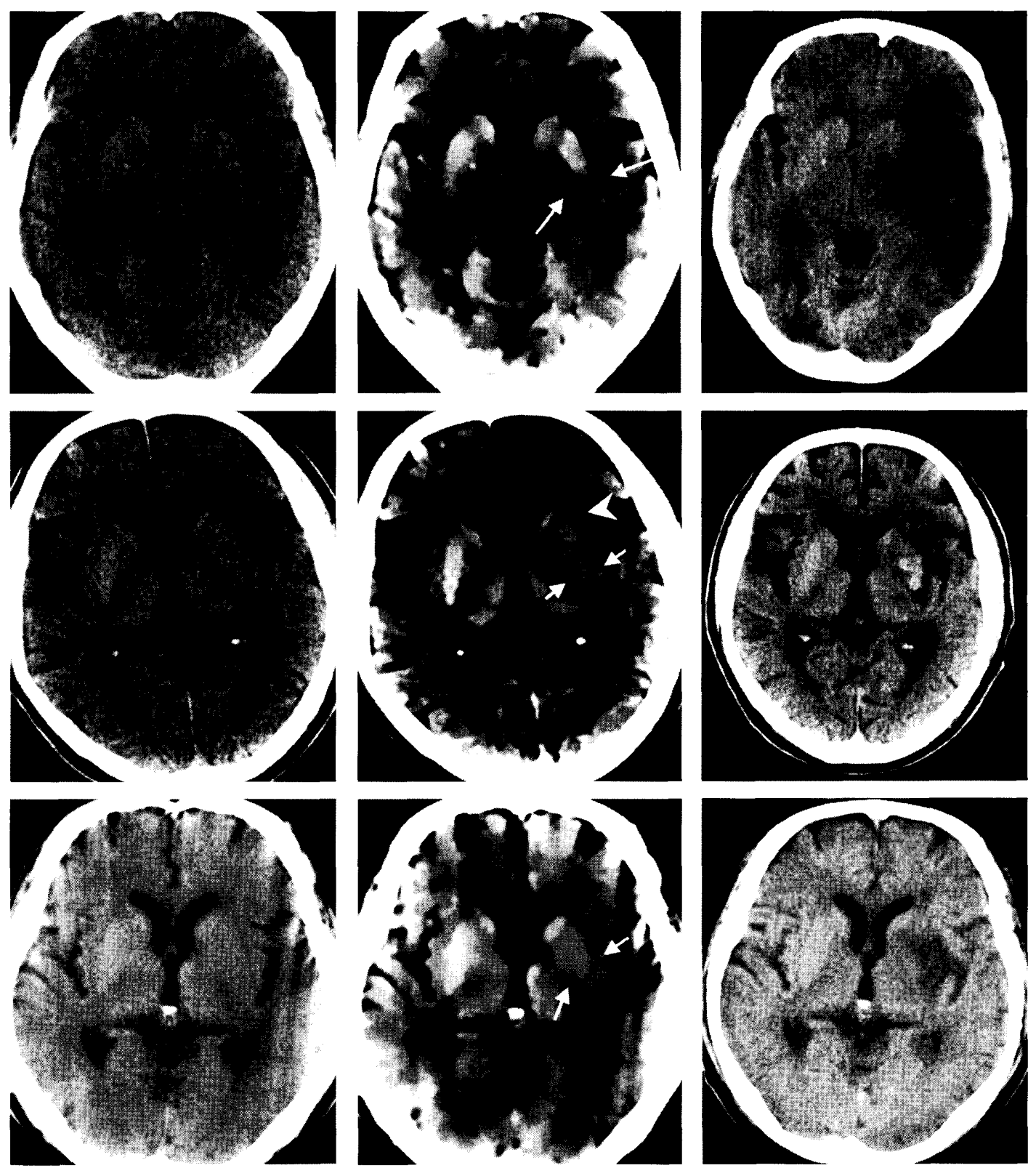

Fig. 7 Nonenhanced CT images of three cases of acute ischemic stroke.

(a) Case 1: original image obtained at $1 \frac{3 / 4}{4}$ hours after stroke onset in a 63 -year-old woman.

(b) Processed image after applying APSF ( $T=2.5$ ) to (a). Arrows indicate partial disappearance of the lentiform nucleus.

(c) Nonenhanced CT image obtained 7 days after the onset of symptoms.

(d) Case 2: original image obtained at $1 \frac{1 / 2}{2}$ hours after stroke onset in an 83-year-old man.

(e) Processed image after applying $\operatorname{APSF}(T=2.5)$ to (d). Arrows indicate obscuration of the lentiform nucleus. Arrowhead indicates loss of the insular ribbon.

(f) Nonenhanced CT image obtained 7 days after the onset of symptoms.

(g) Case 3: original image obtained at $1 \frac{1 / 2}{2}$ hours after stroke onset in a 60-year-old man.

(h) Processed image after applying $\operatorname{APSF}(T=2.5)$ to $(\mathrm{g})$. Arrows indicate obscuration of the lentiform nucleus.

(i) Nonenhanced CT image obtained 7 days after the onset of symptoms. 

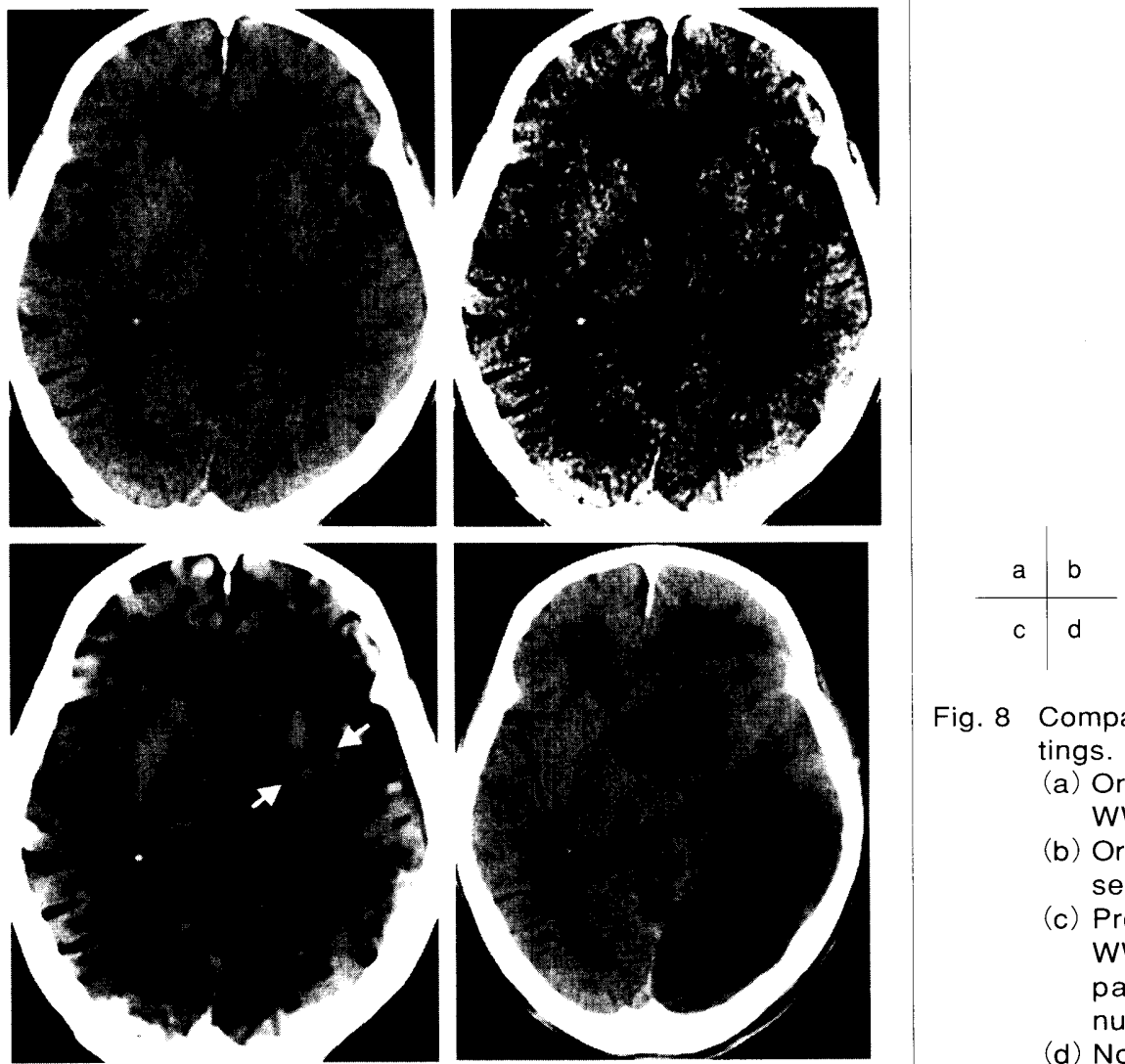

Fig. 8 Comparison of different window width (WW) settings.

(a) Original image obtained by using standard WW setting (WW, $80 \mathrm{HU}$ ).

(b) Original image obtained by using narrow WW setting (WW, $20 \mathrm{HU})$.

(c) Processed image obtained by using narrow WW setting ( $W W, 20 \mathrm{HU}$ ). Arrows indicate partial disappearance of the lentiform nucleus.

(d) Nonenhanced CT image obtained 4 days after the onset of symptoms.

一白質間の不明瞭化が強調され，読影経験にあまり左 灰されずに異常部位を検出することが可能であると考 える。

提案したAPSFと基本的なノイズ低減フィルタであ る移動平均フィルタとメディアンフィルタとをシミュ レーション画像を用いて比較検証した。APSFではフ

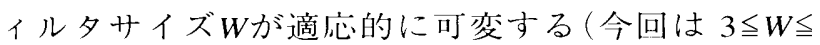
13).そのため比較に用いる移動平均フィルタとメデ イアンフィルタのサイズも $3 \leqq W \leqq 13 の$ 範囲内が望まし い.これら:-つのフィルタサイズは，処理後の画像の SGM領域のSDがAPSF処理後の画像のSGM領域のSD とほぼ同程度になるように決定した。APSFのしきい

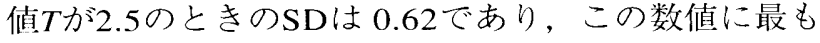
近い值を示したフィルタのサイズは, 移動平均フィル

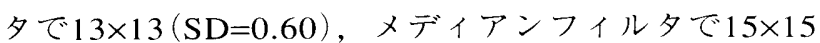
$(\mathrm{SD}=0.61)$ であった.メディアンフィルタのサイズは $3 \leqq W \leqq 130$ 範囲外であるが，比較にはこの二つのフィ ルタサイズをそのまま用いることにした。Tableに APSF, 移動平均フィル夕 $(13 \times 13)$, メディアンフィル 夕 $(15 \times 15)$ のD とSRの值をそれぞれ示す。同程度の SDであるにもかかわらず，APSFが他の二つのフィル 夕と比較して 2 倍以上高いSRを示していることが分 かる.また, Fig. 9にFig. 5の原画像に移動平均フィル
Table Performance comparison of SR for various filters: $\operatorname{APSF}(T=2.5)$, averaging filter, and median filter.

\begin{tabular}{ccc}
\hline Filter & SD & SR $(\%)$ \\
\hline APSF & 0.62 & 60.6 \\
Averaging & 0.60 & 21.3 \\
Median & 0.61 & 31.2 \\
\hline
\end{tabular}

夕 $(13 \times 13)$ ，メディアンフィルタ $(15 \times 15)$ を適用した 画像を示す. Fig. 5のT=2.5の画像と比較したとき，移 動平均フィルタとメディアンフィルタでは明らかに SGMとSWM間のエッジの保存の度令いが低いことが 確認できる，以上のことから，提案したAPSFは従来 の移動平均フィルタとメディアンフィル夕よりも，本 研究の目的に対してより有用性が高いことが示された と考える。

実際の頭部CT画像では，個人善や施設開の撮影条 件の違いによって画像ごとにSDが異なることが想定 される。このことに対して，管電流つまりノイズレべ ルを変えてシミコレーション実験を行うことで，実際 の臨床画像でのSDの違いを考虑したしきい值Tの汱走 が可能であると考えられる。これは重要な今後の課題 


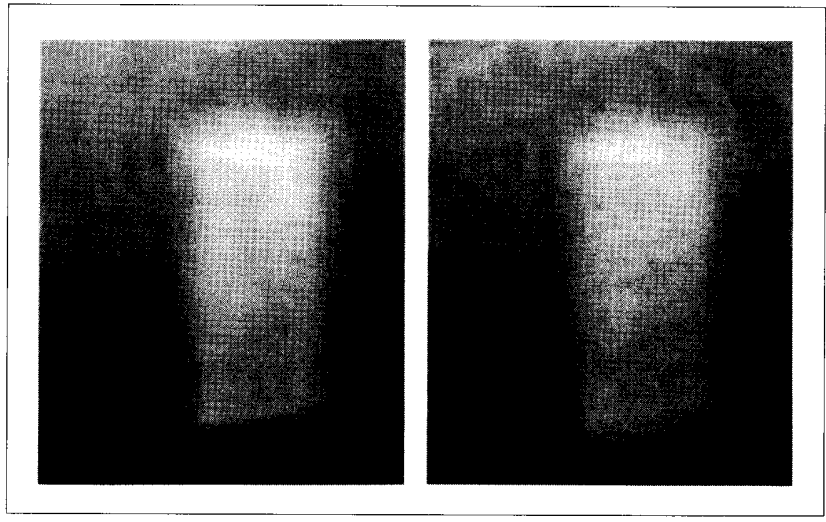

Fig. 9 Results obtained from the computersimulated image after applying (a) $13 \times 13$ averaging filter, and (b) $15 \times 15$ median fil$a \mid b$ ter.

の一つとして挙げられる.

\section{5. 結 語}

急性期脳梗塞の初期虚血変化の描出能を向上させる ことを目的とした画像処理の一手法として適応型部分 移動平均フィルタAPSFを提案した. シミュレーショ ン実験から，本研究の目的に適したAPSFのパラメー 夕（しきい值 $T$ )の基準值を求めた。そして，その基準 値を用いて臨床画像にAPSFを適用した結果，量子，
イズの低減とともにレンズ核の輪郭が明瞭になったこ とで，視覚的に初期虚血変化の描出能が向上するとい う良好な結果が得られた。今後は，本手法をより多く の症例に適用し臨床的有効性をさらに評価していく子 定である。

本論文の要旨は第 16 回欧州放射線医学会議 (ECR2005, Vienna)において発表した。

\section{参考文献}

1) Bryan RN, Levy LM, Whitlow WD, et al.: Diagnosis of acute cerebral infarction: comparison of $\mathrm{CT}$ and MR imaging. AJNR, 12 (4), 611-620, (1991).

2) Adams HP Jr, Adams RJ, Brott T, et al.: Guidelines for the early management of patients with ischemic stroke: A scientific statement from the Stroke Council of the American Stroke Association. Stroke, 34 (4), 1056-1083, (2003).

3) Tomura N, Uemura K, Inugami A, et al.: Early CT finding in cerebral infarction: Obscuration of the Lentiform Nucleus. Radiology, 168(2), 463-467,(1988).

4) Truwit CL, Barkovich AJ, Gean-Marton A, et al.: Loss of the Insular Ribbon: Another Early CT Sign of Acute Middle Cerebral Artery Infarction. Radiology, 176 (3), 801-806, (1990).

5) Yang YQ, Nakamori N, and Yoshida $Y$ : De-noising of Cone beam CT image using wavelet Transform. Proceedings of SPIE, 4684, 1077-1084, (2002).

6) Guis VH, Adel M, Rasigni M, et al.: Adaptive neighborhood contrast enhancement in mammographic phantom images.
Optical engineering, 42(2), 357-366, (2003).

7）千葉怜那, 李 鎔範, 蔡 篤儀: エントロピーに基づく適 応型近傍コントラスト強調法の改良. 日放技学誌, 61 (2), 268-276, (2005).

8) Kirkwood JR: Cerebrovascular disease. Essentials of Neuroimaging second edition. p.82, Churchill Livingstone, (1995).

9) von Kummer R, Meyding-Lamade U, Forsting M, et al.: Sensitivity and prognostic value of early $\mathrm{CT}$ in occlusion of the middle cerebral artery trunk. AJNR, 15(1), 9-15, (1994).

10) Unger E, Littlefield J, and Gado $M$ : Water content and water structure in CT and MR signal changes: possible influence in detection of early stroke. AJNR, 9 (4), 687-691,(1988).

11) Lev MH, Farkas J, Gemmete JJ, et al.: Acute stroke: improved nonenhanced CT detection-benefits of soft-copy interpretation by using variable window width and center level settings. Radiology, 213 (1), 150-155, (1999). 
Fig. 1 適応近傍領域の決定方法 (しきい值 $T=5$ )

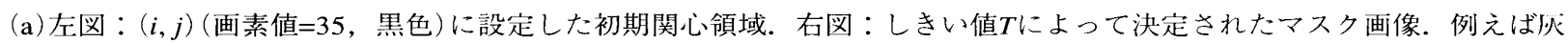
色で示した画素 $(k, l)$ は, $|I(k, l)-I(i, j)| \leqq T$ よ画素值 1 にラベルされる.

(b)フィルタサイズによる各関心領域のP $P_{0}$ を求めWを決定する．例では $P_{0}$ が $60 \%$ を超えないとした場合，W=7に決定

(c) 画素值 1 にマスクされた画素(灰色)に対応する領域の画素值の平均を $(i, j)$ に代入する.

Fig. 2 質を模擬したCTファントム画像 (SWM)に灰白質を模擬した信号 $(\mathrm{SGM})$ を加えて作成したシミュレーション画像

Fig. 3 しきい值Tに関するSDとSRのグラフ
(a)しきい值TとSDとの関係

(b)しきい值TとSRとの関倸

Fig. 4 能力評価に使用した傾斜比(slope ratio：SR)の説明

Fig. 5 しきい值Tを変えたときのAPSF処理後のシミュレーション画像

Fig. 6 しきい值Tを変えてAPSFを適用したときの処理後の頭部CT画像とウィンドウ幅を変えた画像
(a) 原画像
(b) $T=1.5$
(c) $T=2.5$
(d) $T=3.5$
(e) 狭いウィンドウ幅 $(20 \mathrm{HU})$ を用いた (a)の画像
(f) 通常のウィンドウ幅 $(80 \mathrm{HU})$ を用いた (c)の画像

Fig. 73 例の急性期脳梗塞の頭部CT画像とAPSF処理後の画像
(a) 症例 $1:$ 発症 1 時間45分後の63歳女性の頭部CT画像
(b) (a)にAPSF $(T=2.5)$ を適用した画像. 矢印はレンズ核の輪郭の一部欠損を示す.
(c) 発症 7 日後のCT画像
(d) 症例 $2:$ 発症 1 時間30分後の83歳男性の頭部CT画像
(e) (d)にAPSF $(T=2.5)$ を適用した画像. 矢印はレンズ核の輪郭の不明瞭化を示す．矢頭は島皮質リボンの消失を示す.
(f) 発症 7 日後のCT画像
(g) 症例 3: 発症後 1 時間30分後の60歳男性の頭部CT画像
(h) $(\mathrm{g})$ に $\operatorname{APSF}(T=2.5)$ を適用した画像. 矢印はレンズ核の輪郭の不明瞭化を示す.
(i) 発症 7 日後のCT画像

Fig. 8 異なるウィンドウ幅で表示した画像の比較
(a) 通常のウィンドウ幅 $(80 \mathrm{HU})$ で表示した原画像
(b) 狭いウィンドウ幅 $(20 \mathrm{HU})$ で表示した原画像
(c) 狭いウィンドウ幅 $(20 H U)$ で表示したAPSF処理後の画像. 矢印はレンズ核の一部欠損を示す.
(d) 脳梗塞発症 4 日後のCT画像

Fig. 9 各フィルタをシミュレーション画像に適用後の画像
(a) $13 \times 13$ 移動平均フィル夕

(b) $15 \times 15$ メディアンフィルタ 